\title{
AN EMPIRICAL ANALYSIS OF THE WELFARE MAGNET DEBATE USING THE NLSY
}

Phillip B. Levine

David J. Zimmerman

Working Paper 5264

\author{
NATIONAL BUREAU OF ECONOMIC RESEARCH \\ 1050 Massachusetts Avenue \\ Cambridge, MA 02138 \\ September 1995
}

The authors would like to thank seminar participants at the Institute for Research on Poverty and the NBER Summer Institute Meeting on Social Insurance for comments. This research was completed while Zimmerman was in-residence at the Institute for Research on Poverty and Levine was in-residence at the National Bureau of Economic Research. Financial support was provided by the Institute for Research on Poverty. This paper is part of NBER's research program in Labor Studies. Any opinions expressed are those of the authors and not those of the National Bureau of Economic Research.

(c) 1995 by Phillip B. Levine and David J. Zimmerman. All rights reserved. Short sections of text, not to exceed two paragraphs, may be quoted without explicit permission provided that full credit, including $\odot$ notice, is given to the source. 


\title{
AN EMPIRICAL ANALYSIS OF THE WELFARE MAGNET DEBATE \\ USING THE NLSY
}

\begin{abstract}
This paper examines the extent to which differences in welfare generosity across states leads to interstate migration. Using microdata from the National Longitudinal Survey of Youth (NLSY) between 1979 and 1992, we employ a quasi-experimental design that utilizes the categorical eligibility of the welfare system. The pattern of cross-state moves among poor single women with children who are likely to be eligible for benefits is compared to the pattern among other poor households. We find little evidence indicating that welfare-induced migration is a widespread phenomenon.
\end{abstract}

Phillip B. Levine

Department of Economics

Wellesley College

Wellesley, MA 02181
David J. Zimmerman Department of Economics Williams College 34 Sawyer Library Drive Williamstown, MA 01267 


\section{INTRODUCTION}

Recent discussions surrounding welfare reform have stridently asserted the failure of Great Society welfare programs. Much of the hostility has been directed at the joint state-federal program Aid to Families with Dependent Children (AFDC). Proposals for a "new Federalism" currently being advanced would radically alter the balance of power between the federal and state governments by moving much of the authority concerning welfare programs to the state level. States would receive block grants from the federal government and would likely exercise wide discretion in using these funds. This, it is argued, would enhance innovation and ultimately reduce poverty -- both by program innovation and by eliminating perverse incentives associated with existing federal policy.

The debate over which level of government should design and administer welfare policy has a long history, with a crucial issue being the potential for interstate inequality in program benefits to develop in a state level system. This inequality could stimulate migration -- allegedly generating a variety of potentially negative consequences. ${ }^{2}$ Indeed, it is often asserted that traditionally "generous" states such as Wisconsin, New York, and California face a "welfare magnet" phenomenon with low income individuals moving to these states to secure higher benefits.

While the sensitivity of poor people's migration decisions to welfare benefits is crucial to appraising certain public policies, it is also an important factor in establishing the robustness of a great deal of academic research investigating the incentive effects of the welfare system. This literature has utilized the perceived "natural experiment" afforded by the interstate variation in

2 There are a number of different perspectives on the desirability of interstate variation in benefits and its potential consequences. For example, the resulting "variety" of benefit packages could allow people to find locations better matching their preferences (Tiebout, 1956). Alternatively, state governments could react to a perceived in-migration of poor individuals by reducing their welfare benefits. Thus, the threat of "hordes at the gate" could result in a "downward competition" with the final outcome being a less generous welfare system. Indeed, the belief by several state governments that they are welfare magnets has led to calls for a variety of policy changes including benefit reductions, residency requirements (i.e. 2-tier systems), or an increased federal role in establishing uniform benefits. Finally, if individuals do not migrate in response to benefit differentials (perhaps due to financial constraints) the system will result in uneven treatment of the poverty population. 
benefits. $^{3}$ Such variation is thought to provide a set of "miniature laboratories" in which the behavior of poor individuals in more and less generous states can be contrasted to assess the effects of welfare benefits on a variety of behaviors (e.g. labor supply, family formation etc.). This exercise, however, often employs the important maintained hypothesis that state of residence is exogenous -- an assumption violated if welfare-induced migration occurs. Previous research on welfare-induced migration has been hampered by crude definitions of the relevant populations, highly aggregated data, and limited controls for other factors influencing migration. ${ }^{4}$

In this paper we use data from the National Longitudinal Survey of Youth (NLSY) to estimate the magnitude of welfare-induced migration. We employ a conceptually straightforward quasi-experimental approach contrasting the migration decision of a treatment group of individuals eligible for AFDC with controls group that are categorically ineligible. Based on our empirical findings, we find little evidence indicating that welfare benefits have an effect on migration decisions.

\section{TRENDS IN THE LEVEL AND DISPERSION IN WELFARE BENEFITS}

The greater the variation in benefits across states, the more incentive potential welfare recipients have to move. We therefore begin by documenting trends in the dispersion of welfare benefits across states.

Figures 1 and 2 show the distribution of AFDC benefits in 1979 and 1992, respectively, in 1992 dollars. ${ }^{5}$ States shaded darker offer higher benefits. Two things can be noted from these

3 This variation results from the fact that AFDC is a joint state-federal program with states having considerable discretion in setting benefits. Examples of this approach include Zimmerman and Levine (1994) and Currie (1993) among others. Moffitt's (1992) survey of the impact of the welfare system contains many studies using this approach. Also, see Besley and Case (1994) for a discussion of policy endogeneity.

${ }^{4}$ Notable exceptions are studies by Walker $(1993,1994)$ and Blank (1986). Other studies include Frey et. al. (1995), Gramlich and Laren (1984), Hanson and Hartman (1994), and Peterson and Rom (1989). A summary of the relevant research prior to 1979 is provided in Cebula (1979) while the more recent research is summarized and critiqued in Moffitt (1992). Corbett (1991) provides a nice summary of many of the key issues.

5 A state level price index was provided by Steven Craig. Alabama in 1989 is indexed to equal 100 . The index is a population weighted average of city and regional non-metropolitan budgets from the BLS. 
figures. First, average real AFDC benefits have fallen over the period. ${ }^{6}$ For instance, the real AFDC benefit in Pennsylvania fell from $\$ 494$ to $\$ 376$ in 1992 dollars between the two years. Second, the dispersion in real benefits has also fallen as traditionally higher benefit states have cut their real benefit levels by more than traditionally lower benefit states.

The reduced dispersion in welfare benefits over time is affected by the increasing importance of food stamp benefits. ${ }^{7}$ Because food stamp benefits are uniform across states, an increase in the proportion of food stamps in the benefit package would reduce the dispersion in combined benefits. ${ }^{8}$ As shown in Figure 3, in 1973 food stamps comprised about a third of the combined AFDC/food stamp benefit. By 1992 the ratio had risen to about a half.

The trend in benefit variation in AFDC and in combined AFDC plus food stamps across states over time is shown in figures 4-6. These figures represent trends in the ratio of the highest benefit state to the lowest benefit state, the ratio of the 75 th to 25 th percentile in the benefit distribution, and in the coefficient of variation, respectively. All show a significant reduction in benefit dispersion, particularly when food stamp benefits are included. For instance, in 1974 welfare recipients in the highest benefit state (Wisconsin) could obtain AFDC benefits that were nine times greater than the lowest benefit state (Mississippi) and combinded AFDC and food stamp benefits that were almost three times greater. By 1992, these ratios had fallen to about five and two, respectively (between Vermont and Mississippi). Similar comparisons can be made in the other measures of benefit dispersion.

Two principal conclusions can be drawn from these figures. First, benefits vary significantly across states. Second, the dispersion -- though still substantial -- has been falling (1990).

6 This pattern is quite well-known and has been extensively documented by Moffitt

7 Other state-run programs in the social safety net, such as public housing, may affect the dispersion in welfare generosity. Typically, the generosity of these other programs are highly correlated with AFDC benefits. One interesting example is the Medicaid system, that expanded significantly during the 1980's, with some states increasing their eligibility a year or two before others (c.f. Currie and Gruber, 1994). These discrepancies across states, however, were shortterm and more generous welfare states were typically the first to expand eligibility. Incorporating these other programs into the analysis would be unlikely to affect the qualitative findings presented here or the remainder of the paper.

8 The reduction in dispersion is somewhat muted by the fact that food stamp benefits are reduce by 30 cents for each dollar of AFDC receipts. 
through time. This suggests that there is a plausible case to be made for the possibility of welfare motivated migration, though such incentives fell over the last decade or so.

\section{EXPERIMENTAL FRAMEWORK}

\section{A. Hypothetical Randomized Experiment}

A hypothetical experimental study examining the extent of welfare-induced migration could proceed by randomly assigning individuals into a treatment group which would receive welfare benefits and an otherwise identical control group which would not. Subjects would then be distributed across states which differ only by the generosity of their welfare systems (assumed here to be "high" and "low" benefit states for simplicity). We could then observe whether a) the

probability a person moves is associated with their treatment/control status, and b) moves are consistent with a hypothesized welfare motivation. To facilitate the discussion, consider the following transition matrix showing the locational choices of the treatment $(\mathrm{T})$ and control groups (C):

\begin{tabular}{|l|l|l|l|}
\hline $\begin{array}{l}\text { Residence at } \\
\text { time t: }\end{array}$ & Proportion Moving: & Residence at time $\mathrm{t}+1$ : \\
\hline & & High & Low \\
\hline High & $M_{H}^{T}, M_{H}^{C}$ & $M_{H H}^{T}, M_{H H}^{C}$ & $M_{H L}^{T}, M_{H L}^{C}$ \\
\hline Low & $M_{L}^{T}, M_{L}^{C}$ & $M_{L H}^{T}, M_{L H}^{C}$ & $M_{L L}^{T}, M_{L L}^{C}$ \\
\hline
\end{tabular}

where $M_{H}^{T}, M_{H}^{C}$ are the fraction of treatments and controls originally in high benefit states who move and $M_{L H}^{T}, M_{L H}^{C}$ are the fraction of the treatment and control populations (i.e. non-movers are included in the denominator) respectively moving from low benefit states to high benefit states. The notation is analogous for other entries.

\section{B. Implications for the Probability of Moving}

Differential welfare benefits may affect whether a person moves out-of-state. We would expect the following to hold true given the experiment outlined above (i.e. ceteris paribus): 


$$
\begin{aligned}
& \text { (1) } M_{L}^{T}-M_{L}^{C}>0 \\
& \text { (2) } M_{H}^{T}-M_{H}^{C}<0 \\
& \text { (3) } M_{L}^{T}-M_{H}^{T}>0 \\
& \text { (4) } M_{L}^{C}-M_{H}^{C}=0
\end{aligned}
$$

The logic of these implications draws on the fact that treatments and controls are assumed to be the same, on average, except that relative welfare benefits could influence the treatments' migration decision between states that are otherwise identical. Thus, for example, equation (1) states that treatments in low benefit states should be more likely to move than the controls. This is because all else is assumed equal between treatment and controls except the fact that treatments have an added incentive to get higher benefits. Equation (2) similarly suggests that treatments should be less likely to move out of high benefit states. Indeed, in both equations (1) and (2) the control group can be thought of as providing a baseline estimate of the fraction of treatments that would move if there were no incentive to migrate for higher benefits (e.g. if benefits were uniform). Random assignment would cause other factors. (e.g. proximity to family and friends) influencing migration to be similar between the two groups. Equation (3) states that treatments should, ceteris paribus, be more likely to leave low benefit states than high benefit states. In this case we are contrasting treatments across states. Such a comparison is valid so long as these states are identical in all other dimensions, which has been assumed in this hypothetical experiment. This assumption is also implicit in equation (4) which indicates that control group members are equally likely of moving out of high benefit and low benefit states.

\section{Implications concerning the state chosen:}

In addition to differences in the likelihood of moving for the treatment and control groups, we can also place conditions on the relative likelihood of treatment and controls moving to higher or lower benefit states. Again, ceteris paribus, the experiment outlined above suggests:

$$
\begin{aligned}
& M_{L H}^{T}-M_{L H}^{C}>0 \\
& M_{H L}^{T}-M_{H L}^{C}<0 \\
& M_{L H}^{T}-M_{H L}^{T}>0 \\
& M_{L H}^{c}-M_{H L}^{c}=0
\end{aligned}
$$


Equation (5) states that a higher proportion of treatments than controls should move to higher benefit states. 9 That is, the higher benefits should attract the treatments, but not the controls (other things equal). Indeed, if other factors are equal, and if the treatment and control groups are otherwise identical, then the difference shown in (5) would provide an estimate of the fraction of treatment moves that are caused by interstate variation in benefits. i.e. $M_{L H}^{C}$ provides a baseline estimate of the fraction of treatments who would move to higher benefit states in the absence of benefit considerations. Equation (6) is analogous, though opposite in direction. Equation (7) contrasts the movements of treatments from low to high benefit states and high to low benefit states. Other things equal, treatments should be more likely to move from low benefit states to high benefit states than the reverse if other state characteristics are identical. For the same reason, Equation (8) suggests that the fraction of the controls who move to higher benefit states should equal the fraction moving to lower benefit states.

\section{The Natural Experiment}

Although the experimental design outlined above clearly depicts the hypotheses we are interested in testing, there are, of course, many complications involved in implementing it. Foremost among them is that there is no randomized assignment into treatment and control groups. The categorical nature of welfare eligibility, however, allows us to set up a natural experiment similar in nature to the approach just described.

The requirement for membership in the treatment group is the possibility of benefiting from higher welfare benefits. Providing such a classification, however, is not without its pitfalls. Clearly, current welfare recipients should be included in this group. Recent recipients may also be considered potential beneficiaries since the likelihood of subsequent welfare receipt is high among this group. Other low income single women with children may meet the eligibility requirements or be close to meeting these requirements and may face an incentive to move to higher benefit

9 Note that this is not the probability of moving from a low benefit state to a high benefit state conditional on moving. Since the fraction moving could depend on benefit differences comparing conditional differences could yield misleading results. For example, suppose there are 100 people in both the treatment and control populations. Suppose 10 controls and 15 treatments move with 5 controls and 10 treatments respectively moving to a higher benefit state. Then, conditional on moving the treatments are a third more likely to move to a higher benefit state. This estimate is, however, biased downward as shown by the fact that twice as many people from the control versus the treatment population move from a low to a high benefit state. 
states. In this analysis, we classify women with these characteristics as members of the treatment group where "low income" is defined as income below the federal poverty standard.

This classification system may introduce some biases into estimated treatment effects. For example, poor married women with children or poor single women without children may benefit by moving to more generous states if they subsequently get divorced or have a child, respectively. In addition, some women may be poor but are still not categorically eligible for welfare because state AFDC need standards are lower than federal poverty standards. Either of these circumstances would introduce a downward bias on the estimated extent of welfare induced migration. We have tested the sensitivity of our results to alternative definitions of the treatment group and obtained results similar to those presented below. ${ }^{10}$

Our control groups include respondents who are poor, but are otherwise not categorically eligible for AFDC and include: poor single women without children, poor single men, poor married men, and poor married women. No one in the control group has received welfare within (at least) two years. Men, regardless of their economic status, have historically been largely excluded from receiving welfare benefits. Married men and women are largely ineligible because the program AFDC-UP, which provides benefits to couples, is limited. Selecting only poor individuals increases the similarity between the control and treatment groups.

\section{E. Difficulties in Implemention}

There are two main problems in using the treatment and control groups just defined to examine the implications provided in equations (1)-(8) regarding the influence of welfare benefit differentials on migration decisions. First is the possibility that the treatments and controls are different in dimensions other than their welfare eligibility, a likely situation in the absence of true random assignment. It may be more difficult for poor single women with children to move compared to a poor man with no family obligations due to differential costs of mobility, for instance. This condition would yield biased estimates of welfare-induced migration obtained from equations (1), (2), (5), and (6). Second is the fact that states differ in their welfare generosity and

10 In addition to experimenting with different measures of poverty status we have also used alternative specifications for our control and treatment groups. In particular, we have experimented with a treatment group of women who dropped out of high school and a control group who did not. Similar results are obtained using this alternative stratification of the sample. 
a myriad of other characteristics. For example, if low benefit states have a nicer climate, then the flow of treatments out of the state would be reduced relative to the flow of treatments out of higher benefit states with a worse climate. This set of circumstances would indicate that estimates of welfare-induced migration provided by equations (3) and (7) would be biased towards zero.

A potential correction to these problems is possible by applying a difference-in-difference estimator. Instead of estimating equations (1)-(3) or (5)-(7), this approach would estimate

$$
\begin{aligned}
& \left(M_{L}^{T}-M_{H}^{T}\right)-\left(M_{L}^{C}-M_{H}^{C}\right)>0 \\
& \left(M_{L H}^{T}-M_{H L}^{T}\right)-\left(M_{L H}^{C}-M_{H L}^{C}\right)>0
\end{aligned}
$$

or, equivalently

$$
\begin{aligned}
& \left(M_{L}^{T}-M_{L}^{C}\right)-\left(M_{H}^{T}-M_{H}^{C}\right)>0 \\
& \left(M_{L H}^{T}-M_{L H}^{C}\right)-\left(M_{H L}^{T}-M_{H L}^{C}\right)>0
\end{aligned}
$$

This approach is facilitated by two assumptions: (1) control and treatment groups value other state characteristics equally, ${ }^{11}$ and (2) differences in the propensity to move between control and treatment groups are constant in the absence of welfare benefit differentials. The first assumption allows us to control for differences in other state characteristics by comparing migration patterns among control group members in different states. If other differences between states exist, then $M_{L}^{C}-M_{H}^{C}$ and $M_{L H}^{C}-M_{H L}^{C}$ would provide an estimate of the effect of these differences on migration patterns between the states (i.e. the difference in migration we would expect to observe for treatments between the low and high benefit states if welfare differentials did not exist).

11 To illustrate the impact of this assumption failing, suppose that high benefit states are also high tax and low crime states (relative to the low benefit states). Then if treatments care more about crime and controls more about taxes then the fraction of treatments moving out of the low benefit state versus high benefit state would be larger, but the fraction of controls making the comparable move, would be lower. Thus, the control group would not provide a good baseline for the treatments. The more homogeneous the treatment and control group the less likely this is to be a problem. 
Applying this assumption, equations (9) and (10) will provide an estimate of the extent of welfareinduced migration controlling for differences in state characteristics.

The second assumption allows us to correct for differences in the propensity to move. If $M_{L}^{T}-M_{L}^{C}=M_{H}^{T}-M_{H}^{C}=\alpha$, then estimating equations (11) or (12) differences out $\alpha$, which represents the constant difference in the propensity to move. Therefore, this assumption indicates that equations (11) and (12) can provide an estimate of welfare migration unbiased by constant differences in the propensity to move. Thus, the difference-in-difference equations control for both constant differences between the propensities of the treatments and controls to migrate and for observable and unobservable differences between the high and low benefit states.

\section{EMPIRICAL SPECIFICATION}

Although this experimental framework provides useful intuition regarding the analysis we plan to conduct, other shortcomings in this approach require additional statistical solutions. For instance, one significant problem in implementing the experimental design is that there are 51 state AFDC systems with different levels of benefits, not just high benefit and low benefit states. Estimating migration rates between all 51 states is too strenuous a task given the data available for this project. As an alternative, we initially approximate the tests described earlier in the following ways. First, we examine whether the extent of outmigration among treatment group members is higher in states with lower benefits, $\mathrm{dM}^{\mathrm{T}} / \mathrm{dB}<0$. By definition, the treatment effect on control group members must be zero. Therefore, to the extent that $\mathrm{dM}^{\mathrm{C}} / \mathrm{dB}$ does not equal zero, this must be the result of a correlation between benefit levels and some other amenities within states. As in the experimental design suggested earlier, we can difference between control and treatment groups to control for these otherwise unobservable differences in amenities. The statistic, $d M^{T} / d B-d M C / d B$, is analogous to the difference-in-difference statistic represented in equation (9).

One problem with this approach is that it treats the effects of benefit differentials in a linear manner. The estimated effect on outmigration rates in states with, say, a $\$ 20$ higher benefit are constrained to be twice as great as the effect in states with a $\$ 10$ higher benefit relative to a third state. In fact, it may be reasonable to expect discontinuous effects if a welfare eligible 
person is only willing to undertake the costs of moving if they can obtain a large increase in benefits. To examine this alternative hypothesis, we create two dummy variables indicating whether or not an individual living in a particular state could receive a $\$ 100$ or $\$ 200$ benefit increase if they move. Denote these variables $B(100)$ and $B(200)$. We then examine whether $\mathrm{dM} / \mathrm{dB}(\mathrm{z})>0$ for $z=100$, or 200 to determine whether the assumed linear effect on migration in the last method is, in fact, valid. Again, estimating the same statistics for members of the control group and differencing across groups will reduce biases introduced by a correlation between benefits and other state amenities. It also controls for differences in the propensities of the groups to move that are independent of welfare differentials.

Refining this approach further, we note that people may be more willing to move to, say, a state paying $\$ 100$ more if that state is closer to their current state of residence. Therefore, we can also include an interaction between the discontinuous benefit increase variables and the distance to the closest state that pays benefits this much higher than the respondent's home state. ${ }^{12}$ This allows the treatment effect to vary with the distance needed to secure the higher benefit. Yet again, differencing estimates between control and treatment groups can alleviate potential biases introduced by the correlation between benefits and amenities across states.

The analysis described so far examines the decision to move as reflected in equation (9). An extension of this analysis would examine whether or not an individual moves to a higher benefit state as reflected in equation (10). The issues involved in implementing this approach are identical to those just discussed. To generate simple estimates of equation (10) we estimate models where the dependent variable is a dummy variable indicating whether a respondent relocated to a state that provides more generous AFDC benefits. Again, taking differences in parameter estimates between control and treatment groups controls for unobservable differences

12 Given the latitude and longitude of two locations $\left\{\left(\right.\right.$ lat $_{1}$, long $\left._{2}\right)$, (lat 1 - long 2$\left.)\right\}$ the distance is calculated using $\mathrm{D}=69.16 \mathrm{ARCCOS}\left[\operatorname{SIN}\left(\right.\right.$ lat $\left._{1}\right) \operatorname{SIN}\left(\right.$ long $\left._{2}\right)+\operatorname{CoS}\left(\right.$ lat $\left._{1}\right) \operatorname{COS}$ (long$\left.{ }_{2}\right) \operatorname{COS}\left(\right.$ lat $\left.\left._{1}-\operatorname{long}_{2}\right)\right]$. Interacting distance and benefits in this fashion assumes the cost of the move to be linear in distance, a tenuous assumption that has nevertheless been utilized in alternative applications. See, for example, Kane and Rouse (1993) and Kane and Staiger (1994). We would like to thank Doug Staiger for providing these data. 
in states that may be correlated with welfare benefits and in constant differences in the propensity to move between groups. ${ }^{13}$

A final problem that may bias the results of these analyses is that some of the assumptions made in the experimental framework discussed above may not be valid. For example, it is assumed that amenities differing across states are valued similarly by the control and treatment groups. Second, it is assumed that there is a constant difference between the treatment and control groups in their propensity to move. Violation of either of these assumptions would lead to biased results. To partially address these issues we include covariates representing personal and state characteristics in our estimation. To the extent that differences between groups and across states remain after controlling for these factors estimates may still be biased.

Incorporating these modifications to the difference-in-difference approach described above, we estimate several probit equations. The first set of models considers the probability of moving out of one's home state. Using a continuous measure of benefits we estimate a model of the form:

$$
P\left(M_{i j t}=1\right)=F\left(\alpha_{0}+\alpha_{1} T_{j j t}+\alpha_{2} B_{i j t}+\alpha_{3} B_{i j t} \times T_{i j t}+\gamma_{1} X_{i j t}+\gamma_{2} S_{j t}\right) .
$$

where $M_{i j t}$ is a dummy variable equaling one if the individual moves and zero otherwise, $B_{i j t}$ is the combined real AFDC and Food stamps benefit level for a family of two, $T_{i j t}$ is a dummy variable indicating whether the individual is in the treatment group, $X_{i j t}$ is a vector of individual characteristics, $S_{j t}$ is a vector of state characteristics, $\mathrm{i}, \mathrm{j}$, and $\mathrm{t}$ index individuals, states, and years, respectively, and $F$ is the standard normal distribution function. The coefficient $\alpha_{3}$ in equation (13) represents the negative of the difference-in-difference statistic in equation (9).

13 This approach may be problematic because it may obscure differences between states that offer a few dollars more than the respondent's home state and states that offer a few hundred dollars more. As an alternative, we have also estimated Tobit models where the dependent variable is the change in welfare generosity between the respondent's state of residence at time $t$ and the state of residence at time $t+1$. These estimates yield similar conclusions to those of the reported probits and are not reported. 
Additional models are estimated that allow for the effects of benefit differentials to be nonlinear and for the effect of benefit differentials to vary by distance. These models are specified as:

$$
P\left(M_{i j t}=1\right)=F\left(\begin{array}{l}
\beta_{0}+\beta_{1} T_{i j t}+\beta_{2} B(100)_{j t}+\beta_{3} B(200)_{j t}+ \\
\beta_{4} B(100)_{j t} \times T_{i j t}+\beta_{5} B(200)_{j t} \times T_{i j t}+ \\
\gamma_{1}^{\prime} X_{i j t}+\gamma_{2} S_{j t}
\end{array}\right)
$$

and

$$
P\left(M_{i j t}=1\right)=F\left(\begin{array}{l}
\beta_{0}+\beta_{1} T_{i j t}+\beta_{2} B(100)_{j t}+\beta_{3} B(200)_{j t}+ \\
\beta_{4} B(100)_{j t} \times T_{i j t}+\beta_{5} B(200)_{j t} \times T_{i j t}+ \\
\beta_{6} D B(100)_{j t}+\beta_{7} D B(200)_{j t}+ \\
\beta_{8} D B(100)_{j t} \times T_{i j t}+\beta_{9} D B(200)_{j t} \times T_{i j t}+ \\
\gamma_{1}{ }^{\prime} X_{i j t}+\gamma_{2} S_{j t}
\end{array}\right) .
$$

where $B(100)_{j t}$ is a dummy variable indicating whether a two person family could obtain between $\$ 100$ - $\$ 199$ more in benefits by moving, $B(200)_{j t}$ is a dummy variable indicating whether a two person family could obtain $\$ 200$ or more in benefits by moving, $D B(100)_{j t}$ is the distance a person would have to move to obtain between $\$ 100$ - $\$ 199$ more in benefits by moving interacted with $\mathrm{B}(100), D B(200)_{j t}$ is the distance a person would have to move to obtain $\$ 200$ or more in additional benefits by moving interacted with $\mathrm{B}(200)$, and all other notation is defined above. ${ }^{14}$ In these models, nonlinearities in the treatment effect are estimated through the parameters $\beta_{4}$ or $\beta_{5}$ and differences in treatment effects by distance are estimated through the parameters $\beta_{8}$ and $\beta_{9}$.

14 The omitted category is states in which increases of $\$ 100$ or more are not possible. While these states vary across years, in 1990 they included CA, CT, MA, MI, MN, NY, and WI. The lowest benefit states (those for which a $\$ 200+$ increase was possible) included $A L, A Z, A R$, $\mathrm{N}, \mathrm{KY}, \mathrm{LA}, \mathrm{MS}, \mathrm{SC}, \mathrm{TN}, \mathrm{TX}, \mathrm{VA}, \mathrm{WV}$. 
Models of locational choice are then estimated. These models differ from those just presented in that the dependent variable is equal to unity if the individual moves to a higher benefit state. In all other dimensions, these models are identical to those just described.

\section{DATA}

We use the National Longitudinal Survey of Youth (NLSY) to estimate the models just presented. This survey began collecting data on respondents between the ages of 14 and 21 in 1979 and has been repeated annually since then. The panel employed in this research spans 19791992. Blacks, Hispanics, and poor Whites are oversampled at twice their rate in the population, but sampling weights are provided to create parameter estimates representative of the population as a whole. ${ }^{15}$ We merge data for the maximum two person welfare benefit (including food stamps and AFDC) for each state/year onto the NLSY sample. ${ }^{16}$ All dollar values are deflated using a state level price deflator.

The NLSY data provide significant advantages for the purposes of this project. First, supplemental geocode files are available that allow us to determine whether or not an individual moved across state lines between any two years of the panel. Second, the higher propensity of youth to move provides us with a substantial number of cross-state moves over the 14 year period. Third, these data provide a wealth of information about each respondent, including demographic characteristics, family income, AFDC status, and characteristics of an individual's county of residence, that will be quite useful in this analysis.

The format of these data also provide another statistical advantage compared to using nationally representative data. One problem in examining the welfare magnet hypothesis is that states that provide high benefits in one period are quite likely to provide high benefits in subsequent periods. Therefore, if we look at a cross-section of the population, it may consist of welfare migrants who have already moved to the location that will provide them with high benefits. This will lead to a downward bias in estimates of the welfare magnet effect. The

15 Estimates with and without weights yield very similar results. The reported estimates are unweighted.

${ }^{16}$ The results are not sensitive to whether we use AFDC benefits or the combined AFDC and food stamp benefit package. 
youthfulness of the NLSY respondents lessens this problem since most respondents were still living in their parent's household in 1979 and have not yet made their own migration decisions.

These data have significant advantages over other datasets that could be used for studying the issue of welfare-induced migration. In particular, Census data provides the main alternative source. These data contain many more observations per state, but has some serious limitations. First, it measures migration at just two points over a five year window (e.g. 1975 and 1980). Movements within this period are not observed. Second, determining individuals that would become "treatment group" members is difficult because it only provides an income measure within the five year window (i.e. 1979). This income could reflect either pre- or post-migration income and could, therefore be endogenous.

\section{SAMPLE CHARACTERISTICS}

Descriptive statistics for the NLSY sample are presented in Tables 1 and 2. Table 1 reports sample sizes for the treatment and control groups. The element of observation is a person year. Of the 18,782 person years observed for the combined control and treatment sample over the 1979-1992 period in the NLSY, 1052 or about $5.6 \%$ move to a different state. In addition, 519 or $2.7 \%$ move to a higher benefit state. Of the 7,611 observations in the treatment sample, $3.8 \%$ move and $1.8 \%$ move to a higher benefit state. Only $0.8 \%$ of the treatment population move to a higher benefit state and take up welfare immediately with $0.9 \%$ doing so within two years. For the control group, of the 11,171 observations, 763 or $6.8 \%$ move to a different state. Roughly half, or $3.4 \%$ move to a higher benefit state.

This table illustrates the important tradeoff in this analysis between the power of the hypothesis being tested and the power of the statistical procedures employed. The strongest test of the welfare magnet hypothesis would involve observing people move to higher benefit states and taking up welfare after the move. Statistically, however, estimating these joint hypotheses may provide a weak test because of the imprecision arising from the small cell sizes. Alternatively, we could test whether out of state migration among treatment group members is higher relative to control group members. This test, while testing weaker implications of the theory, is statistically more powerful because of the larger cell sizes available. Our approach in 
this paper is to examine a range of hypothesis recognizing the tradeoff between the strength of the theoretical implication and the statistical power of the test.

Table 2 presents sample means for the NLSY data. The treatment and control groups differ somewhat with treatments being more likely to be black and live in higher benefit states. Importantly, estimates indicate that members of the different control groups are somewhat more likely to move than members of the treatment group. Roughly 5-7.5\% of control group members are observed moving across state lines between one year and the next compared to just under $4 \%$ of treatment group members. These statistics underscore the value of our difference-in-difference approach.

\section{EMPIRICAL RESULTS}

Table 3 presents the probit estimates for equations (13)-(15) in specifications that exclude individual and state characteristics. Models were estimated separately for each of the four control groups defined above and were then estimated for one pooled control group. The first row of the table, labelled "Continuous Treatment Effects," represents esimates of $\alpha_{3}$ in equation (13). These coefficients would be expected to be negative, with higher benefits reducing the out-migration of treatments relative to controls. Here we can see that a $\$ 100$ increase in benefits actually increases the probability the treatments move by .252 percentage points relative to control group 1 . The effect is smaller, but still positive, when comparing with control group 2. Estimates are negative for control groups 3 and 4 and for the pooled control group. Importantly, none of the estimates are statistically difference from zero.

The following block of the table, labelled "Discrete Treatment Effects" provides parameter estimates for equations (14) and (15). The "Basic Model" (equation 14) reports estimates of $\beta_{4}$ and $\beta_{5}$ from equation 14 and the "Distance Model" (equation 15) reports estimates of these parameters plus the distance interaction terms, $\beta_{8}$ and $\beta_{9}$. In these models, the welfare magnet hypothesis would be supported if the potential for a large benefit increase led to a greater probability of moving. That probability should decrease if the distance necessary to obtain the 
higher benefits is greater. In both models, point estimates often have signs opposite from those hypothesized and the estimated parameters are uniformly insignificantly different from zero.

Table 4 repeats the estimation of equations (13)-(15), but now includes controls for individual's age, education, the state per-capita income, the state crime rate, and the local unemployment rate. Again, there is no strong evidence that the treatments are more likely to move from low versus high benefit states than the controls. The estimated coefficients are all statistically insignificant. Distance also has no significant effect on the magnitude of the treatment effect here

Tables 5 and 6 are analogous to the two previous tables except the dependent variable is now a dummy variable indicating whether a person moved to a higher benefit state. The results are comparable to those for the probability of moving. Contrary to the welfare magnet hypothesis, treatments are typically less likely to move to a higher benefit state, though parameter estimates are imprecise. Again, the effect does not vary with distance.

Taken as a whole, these results provide little evidence that those women most likely to be candidates for AFDC are moving to take advantage of benefit differentials across states. Parameter estimates of interest are uniformly insignificant and often have the opposite sign to that hypothesized.

\section{SUBSTANTIVE CONSIDERATIONS}

An alternative interpretation of these findings may be valid, however. The inability to reject the null that treatment and controls respond differently to the geographic dispersion in welfare generosity could also reside in the imprecision of our estimates. Significance tests that find no statistical difference between the behavior of treatment and control groups indicate that the parameter estimates are small relative to the standard error. If those standard errors are large, such tests will be very weak.

To examine this argument in more detail, we conduct a simulation exercise designed to provide a conservative upper bound on the extent of welfare-induced migration and its effect on welfare caseloads in generous states. This exercise divides states into three categories, low benefit states, in which a $\$ 200$ or more benefit increase is possible, middle benefit states, in which 
a $\$ 100-\$ 199$ benefit increase is possible, and the remainder of high benefit states. We then simulate the effect on the welfare caseload in the high benefit states using generous assumptions about the extent of migration from the other two groups of states.

The basis for this simulation is the upper bound of the $95 \%$ (one-tailed) confidence interval of the point estimates obtained from the "Basic Model" reported in Table 3 using the pooled control group $\left(\beta_{4}+1.645 \sigma_{\beta_{4}}\right.$ and similarly for $\left.\beta_{5}\right)$. We assume (counterfactually) that all migrants from lower benefit states move to high benefit states. With point estimates of -.057 and -.943 and a standard error of .954 and .851 in low and middle benefit states, respectively, plausible upper bounds on the difference in outmigration rates between treatment and control groups in these lower benefit states is 1.51 and .457 respectively. The product of these estimates and the population of plausibly welfare-eligible women in the low and middle benefit states indicates the number of welfare-induced movers in any given year. ${ }^{17}$ We then assume that the typical mover will stay on the welfare rolls in their new locations for three years. ${ }^{18}$ In steady state, these movers will accumulate in the high benefit states to the level of three times the number of annual movers. A generous estimate of the fraction of the welfare caseload in high benefit states that are out-of-state migrants may be formalized as:

Steady State Impact $=\frac{n_{100}\left(\beta_{4}+1.645 \sigma_{\beta_{4}}\right) D_{100}+n_{200}\left(\beta_{5}+1.645 \sigma_{\beta_{s}}\right) D_{200}}{C_{0}}$

17 The number of families on AFDC in the high benefit states in 1991 was approximately 1.6 million. The number of poor single women with children in the middle and low benefit states was approximately 2.3 million and 1.2 million, respectively. These last estimates were obtained by taking the size of the welfare rolls in these groups of states and multiplying by the ratio of women in this demographic group to women on welfare in our NLSY sample.

18 This assumption is longer than the median duration of welfare receipt actually observed, which is only about 2 years (Hoynes and Macurdy, 1994). We have chosen this higher level because the selection of those recipients who have moved to collect benefits is likely to lead to longer than usual spells. 
where $\mathrm{N}_{100}$ and $\mathrm{N}_{2} 00$ are the number of treatments in the middle and low benefit states, respectively, $D$ represents the assumed median duration of benefit receipt, and $C_{0}$ is the initial caseload in the generous states.

The results of this simulation suggests that an upper bound of the impact of welfareinduced migration on caseloads in high benefit states is approximately $5 \%$. That is, caseloads in generous states are most likely no more than $5 \%$ higher than they would be in a system with uniform benefits across states. In all likelihood, the effect is actually smaller than that.

VII. Conclusions

In this paper we present an empirical evaluation of the welfare magnet hypothesis using data from the National Longitudinal Survey of Youth. We employ a conceptually straightforward quasi-experimental approach contrasting the migration decision of a treatment group of individuals eligible for AFDC with a control group that are categorically ineligible.

The results suggest little evidence that those women most likely to be candidates for AFDC move in a pattern consistent with the welfare magnet hypothesis. They are no more likely to move from low versus high benefit states than other poor individuals not eligible for AFDC. Neither are they more likely to move to a higher benefit state. This suggests that either other factors dominate their decision to move or that the perceived costs associated with moving exceed any potential gain from increased benefits. Conservative estimates suggest the steady state caseloads in generous states increase by $5 \%$, at most, by welfare motivated migration. 


\section{$\underline{\text { References }}$}

Besley, Timothy, and Anne Case, "Unnatural Experiments? Estimating the Incidence of Endogenous Policies," mimeo, 1994.

Blank, Rebecca, "The Effect of Welfare and Wage Levels on the Location Decisions of FemaleHeaded Households," Journal of Urban Economics, September 1988, pp. 186-211.

Case, Anne, James Hine, and Harvey Rosen, "Copycatting: Fiscal Policies of States and Their Neighbors," NBER Working paper, July 1989.

Cebula, Richard, "A Survey of the Literature on the Migration-Impact of State and Local Government Policies," Public Finance, 1979.

Corbett, Thomas, "The Wisconsin welfare magnet debate: What is an ordinary member of the tribe to do when the witch doctors disagree?," Focus, Volume 13, 1991.

Currie, Janet and Jonathan Gruber. "Saving Babies: The Efficacy and Cost of Recent Expansions of Medicaid Eligibility for Pregnant Women." NBER Working Paper \# 4644, February, 1994.

Ellwood, David T. and Mary Jo Bane. "The Impact of AFDC on Family Structure and Living Arrangements." in Ronald G. Ehrenberg (ed.), Research in Labor Economics. Volume 7, 1985. pp. 137-207.

Frey, William et. al., "Interstate Migration of the US Poverty Population: Immigration 'Pushes' and Welfare Magnet 'Pulls'," mimeo, 1995.

Gramlich, E. and D. Laren, "Migration and Income Redistribution Responsibilities," The Journal of Human Resources, Fall 1984.

Hanson, Russell and John Hartman, "Do Welfare Magnets Attract?," Institute for Research on Poverty Discussion Paper \#1028-94, 1994.

Hoynes, Hilary and Thomas MaCurdy, "Has the Decline in Benefits Shortened Welfare Spells," American Economic Review, May 1994, pp. 43-48.

Kane, Thomas, and Douglas Staiger, "Teen Motherhood and Abortion Access," mimeo, 1994.

Kane, Thomas, and Cecilia Rouse, "Labor Market Returns to Two and Four Year Colleges: Is a Credit a Credit and Do Degress Matter?", American Economic Review, forthcoming.

Moffitt, Robert, "Has State Redistribution Policy Become More Conservative?," National Tax Journal, Summer 1990.

Economics. 1990. pp. 101-124.

"The Effect of the U.S. Welfare System on Marital Status." Journal of Public 
Economic Literature, March, 1992.

"Incentive Effects of the U.S Welfare System: A Review," Journal of

Peterson, Paul and Mark Rom, "American Federalism, Welfare Policy, and Residential Choices," Political Science Review, September 1989, pp. 711-728.

Schram, Sanford and Gary Krueger, "Interstate Variation in Welfare Benefits and the Migration of the Poor: Substantive Concerns and Symbolic Responses," Institute for Research on Poverty Discussion Paper \#1032-94, 1994.

Tiebout, Charles, “A Pure Theory of Local Expenditures,” Journal of Political Economy, 1956.

U.S Congress, Committee on Ways and Means, 1992 Green Book, Washington, DC: U.S Government Printing Office, 1992.

Walker, James, "Migration Among Low-Income Households: Helping the Witch Doctors Reach Consensus," Institute for Research on Poverty Discussion Paper \#1031 -94, 1994.

Wisconsin Expenditure Commission, "Report of the Welfare Magnet Study Committee," (Department of Administration: Madison Wisconsin), 1986

Zimmerman, David J., and Phillip B. Levine, "The Intergenerational Correlation in AFDC Participation: Welfare Trap or Poverty Trap?," Wellesley College, Department of Economics Working Paper \#93-07, November 1993. 


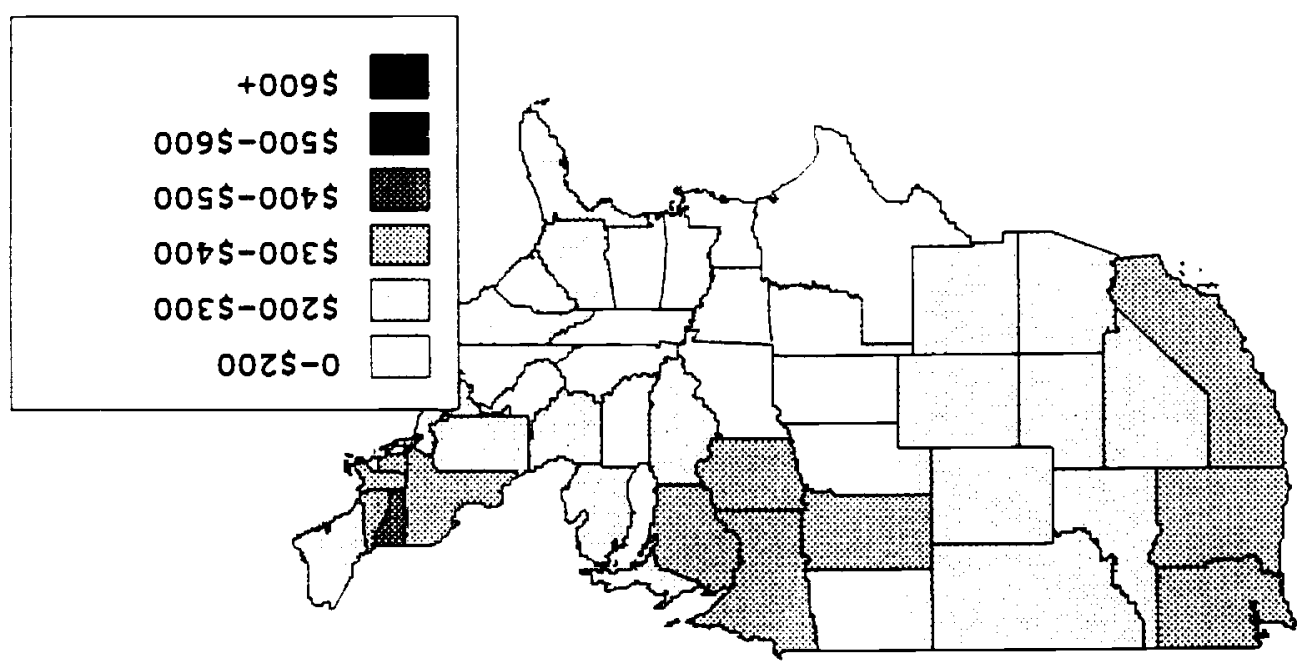

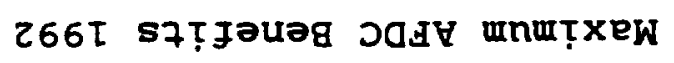

ว $\sin 6 !\rfloor$

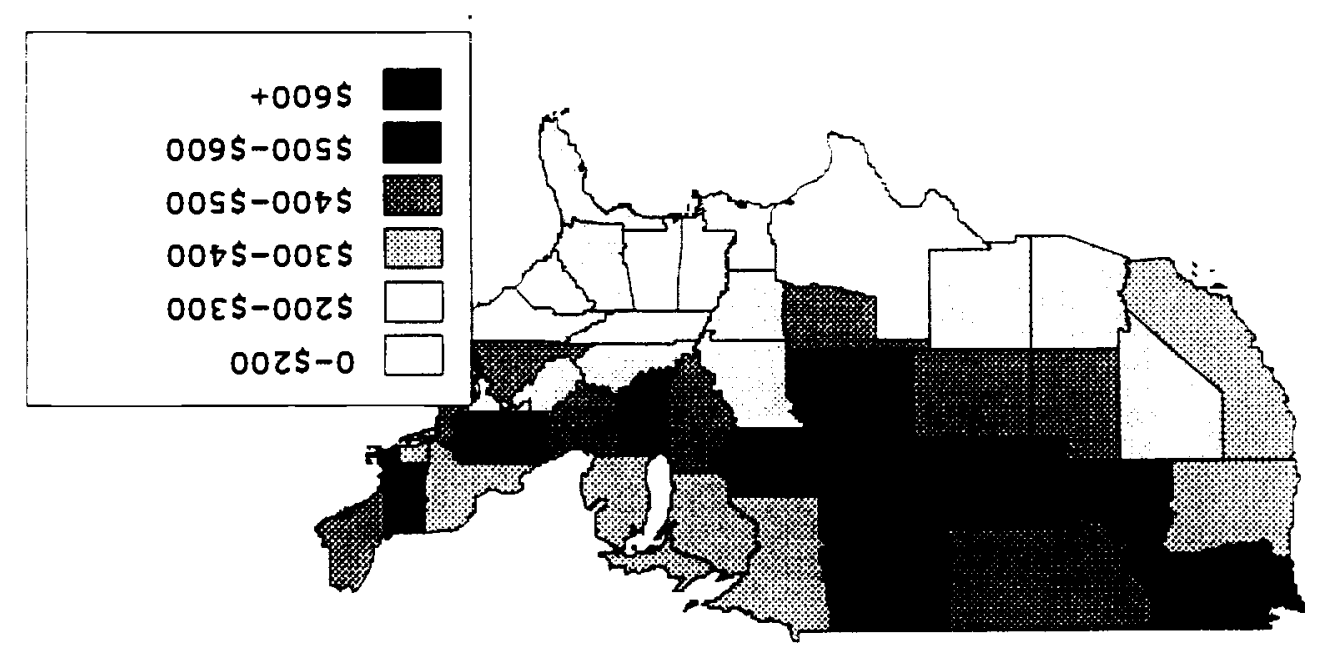

6L6I S7ṬJəuəg Jast unm

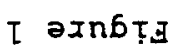


Figure 3: Fraction of Food Stamp Benefits to Combined

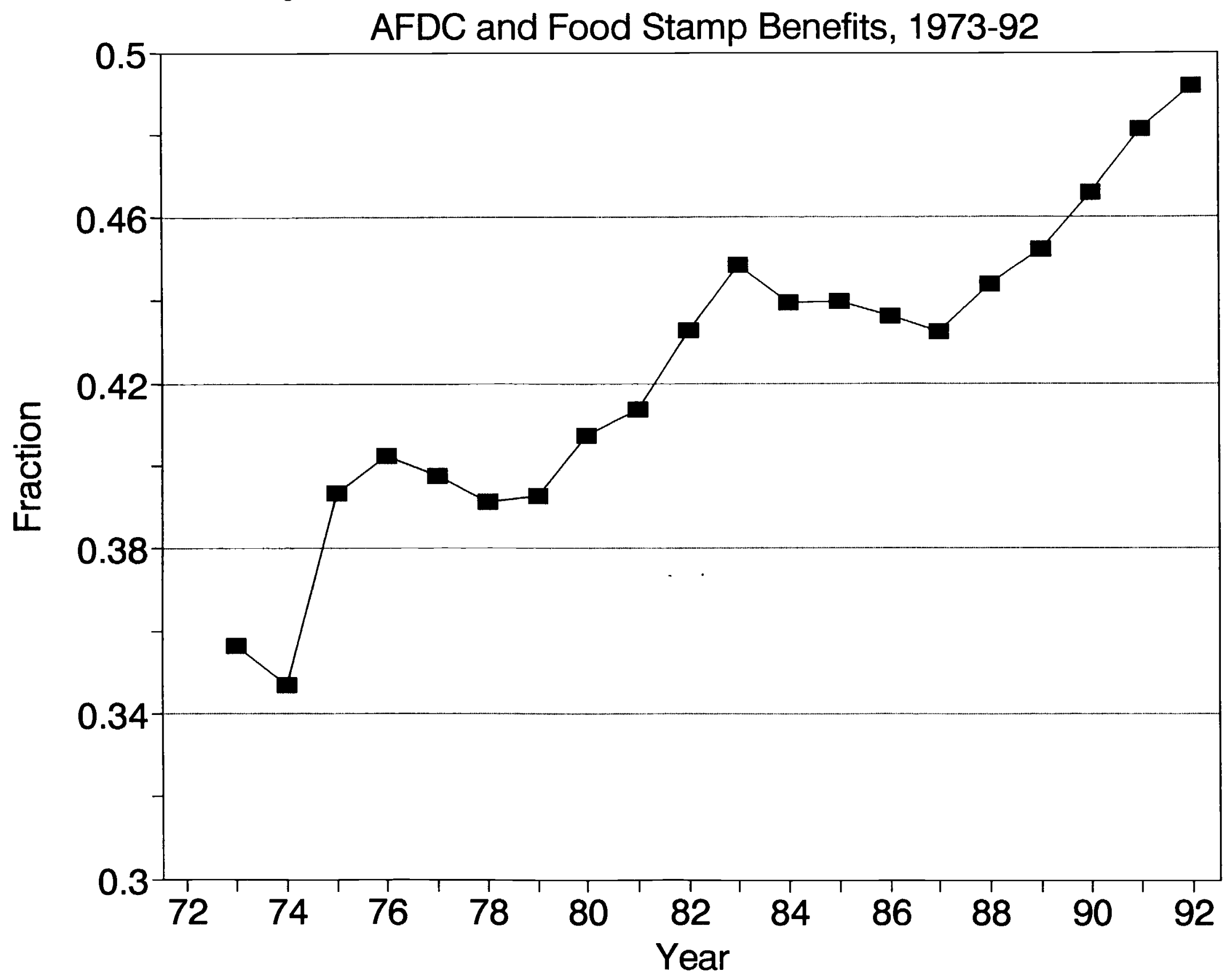


Figure 4: Ratio of Maximum to Minimum Welfare Benefits, 1973-1992

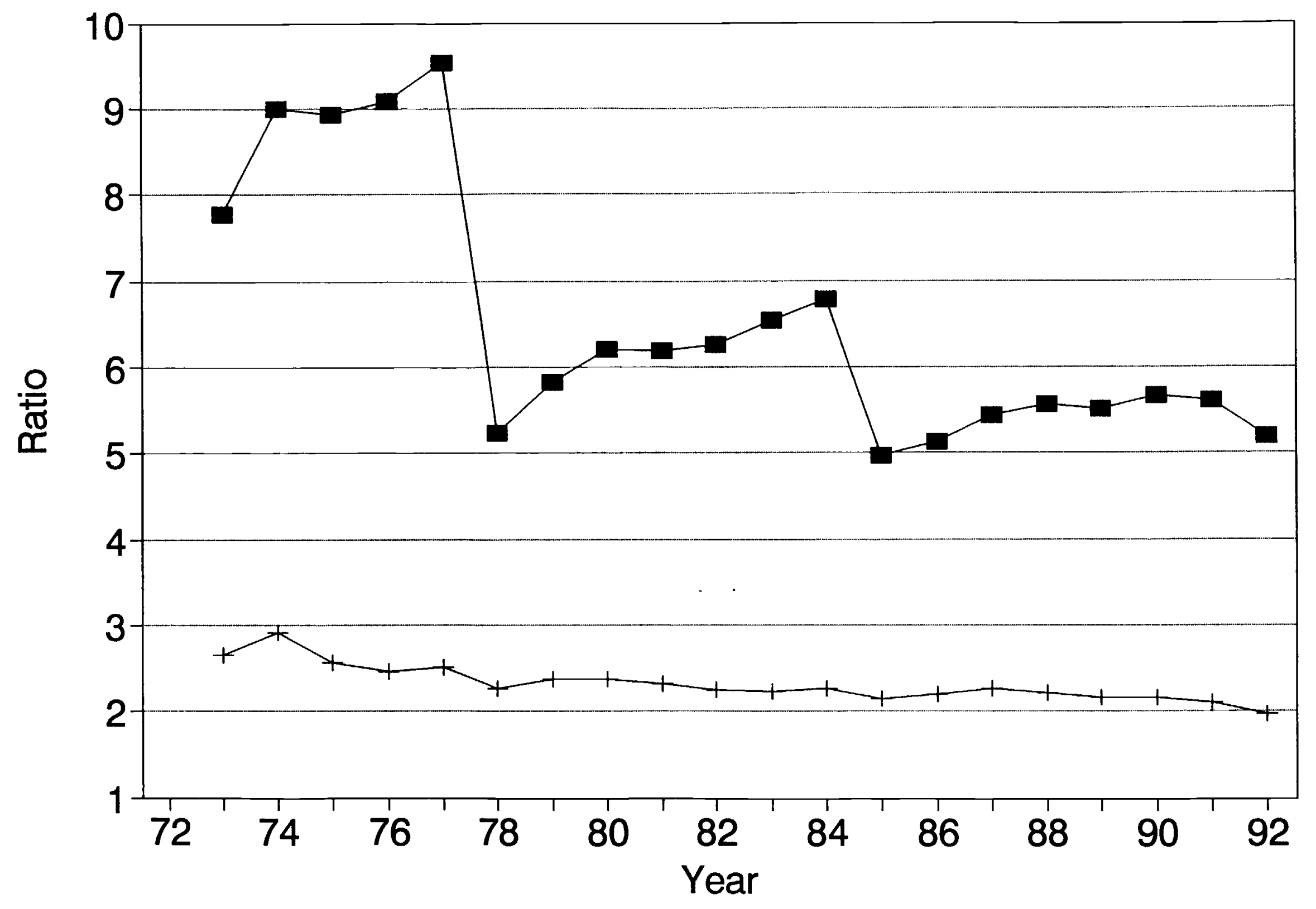

$\rightarrow$ AFDC only $\quad+$ AFDC/Food Stamps 
Figure 5: Ratio of 75th Percentile to 25th Percentile in

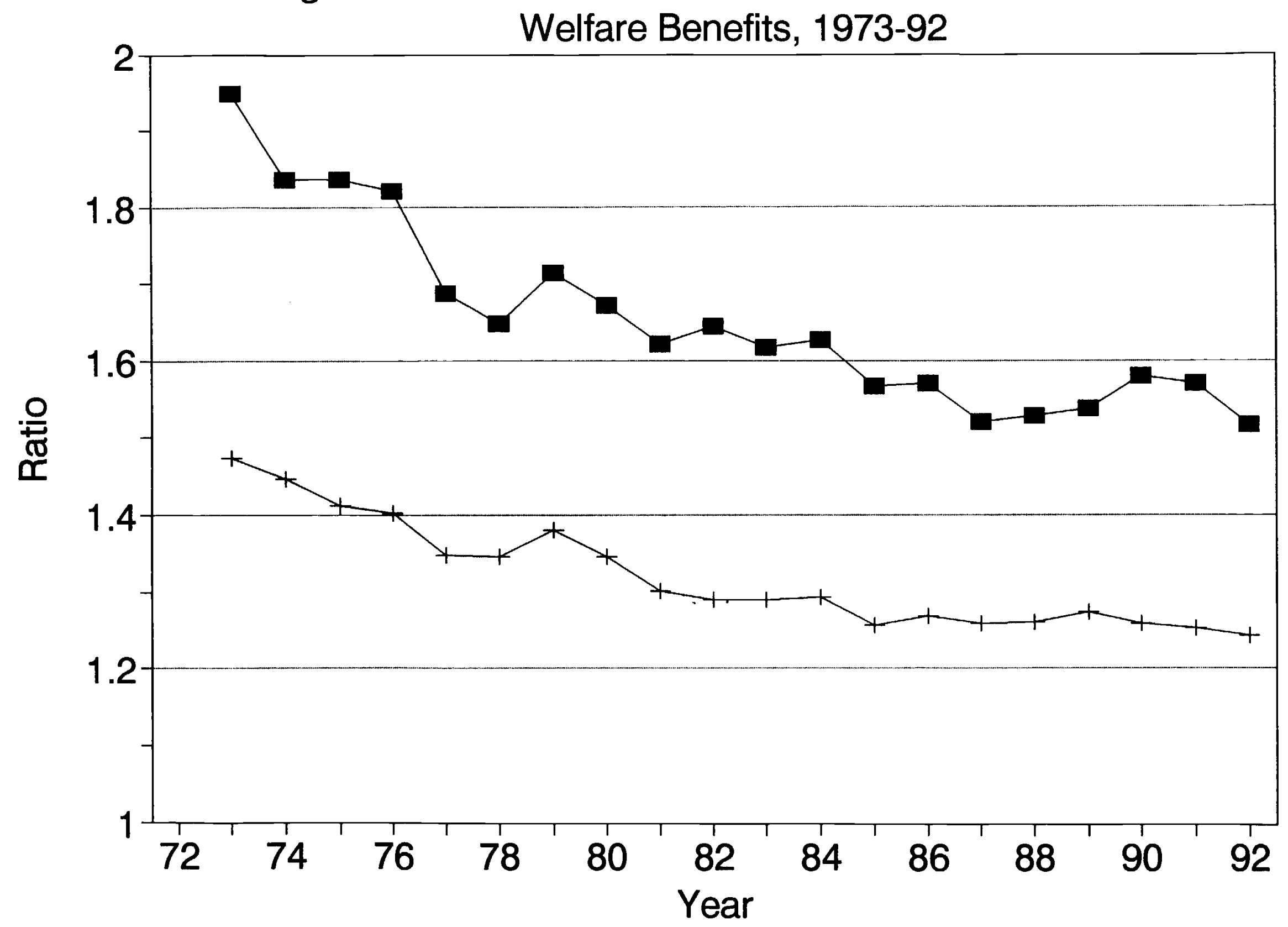

$\rightarrow$ AFDC only $\quad$ - AFDC/Food Stamps 
Figure 6: Coefficient of Variation in Welfare Benefits, 1973-1992

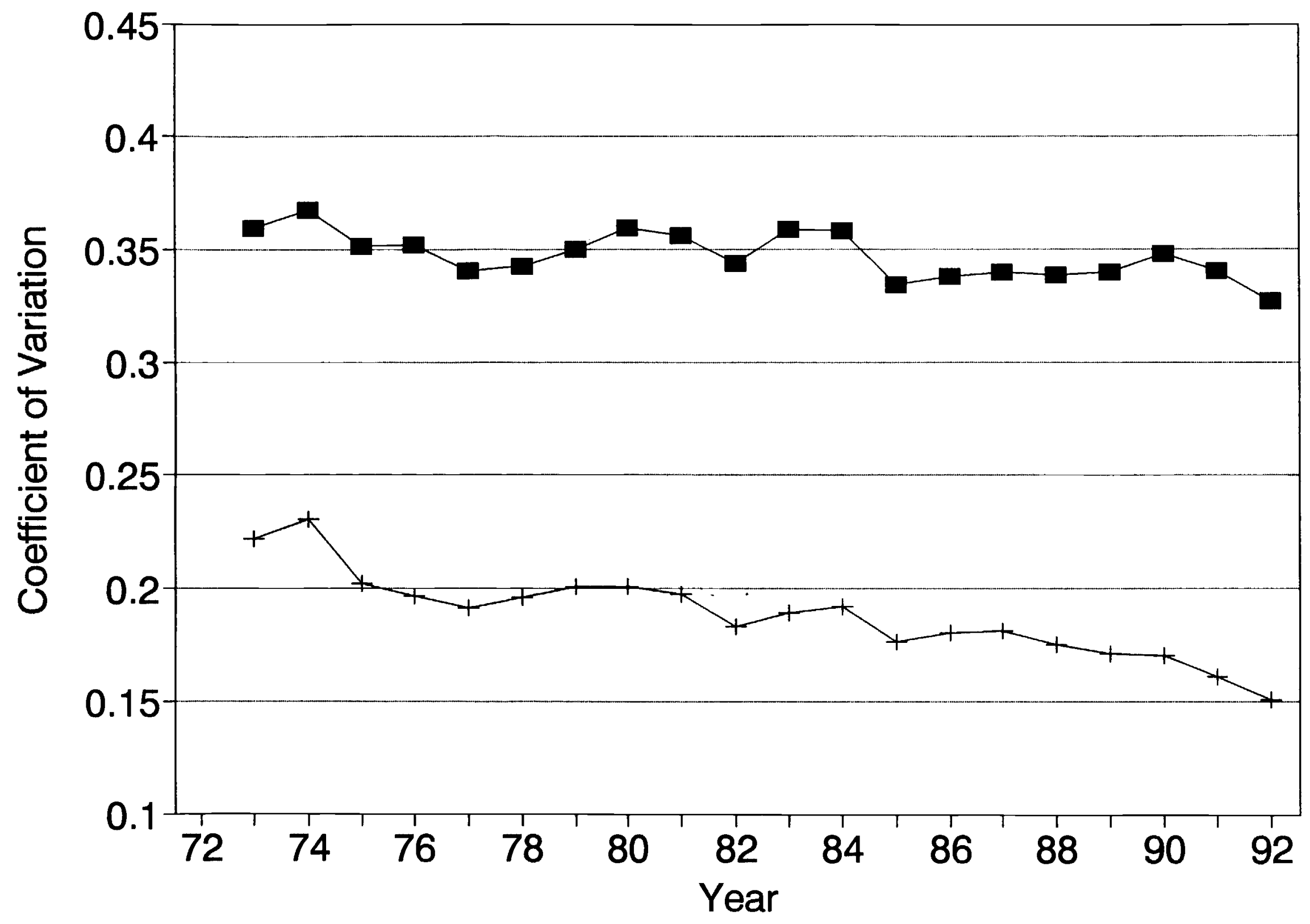

- AFDC only $\quad$ - AFDC/Food Stamps 
TABLE 1

Treatment and Control Sample Sizes

\begin{tabular}{|c|c|c|c|c|c|c|c|}
\hline & $\begin{array}{c}\# \\
\text { person- } \\
\text { years }\end{array}$ & (n) moving & $\begin{array}{c}\text { moving }(n) \text { to } \\
\text { a higher benefit } \\
\text { state }\end{array}$ & $\begin{array}{l}\text { (n) moving } \\
\text { and taking } \\
\text { up AFDC } \\
\text { within one } \\
\text { year of } \\
\text { moving }\end{array}$ & $\begin{array}{l}\text { (n) moving } \\
\text { and taking } \\
\text { up AfDC } \\
\text { within } 2 \\
\text { years of } \\
\text { moving }\end{array}$ & $\begin{array}{l}\text { (n) moving } \\
\text { to a higher } \\
\text { benefit state } \\
\text { and taking up } \\
\text { AFDC within } \\
\text { one year of } \\
\text { moving }\end{array}$ & $\begin{array}{l}\text { (n) moving } \\
\text { to a higher } \\
\text { benefit state } \\
\text { and taking up } \\
\text { AfDC within } \\
\text { one year of } \\
\text { moving }\end{array}$ \\
\hline \multicolumn{8}{|l|}{ Treatment Groups } \\
\hline $\begin{array}{l}\text { Single women on AFDC in } t \text { or } \\
t-1 \text { (Treatment } 1)\end{array}$ & 5690 & $\begin{array}{l}3.37 \\
(192)\end{array}$ & $\begin{array}{l}1.5 \\
(86)\end{array}$ & $\begin{array}{r}2.2 \\
(124)\end{array}$ & $\begin{array}{l}2.4 \\
(137)\end{array}$ & $\begin{array}{l}.9 \\
(53)\end{array}$ & $\begin{array}{l}1.0 \\
(58)\end{array}$ \\
\hline $\begin{array}{l}\text { Poor single women with } \\
\text { children, not on AfDC in } t \\
\text { or } t-1 \text { (Treatment } 2 \text { ) }\end{array}$ & 1921 & $\begin{array}{l}5.05 \\
(97)\end{array}$ & $\begin{array}{l}2.6 \\
1501\end{array}$ & $\begin{array}{l}.8 \\
(16)\end{array}$ & $\begin{array}{l}1.2 \\
(23)\end{array}$ & $\begin{array}{l}.4 \\
(9)\end{array}$ & $\begin{array}{c}.6 \\
(12)\end{array}$ \\
\hline Total Treatments & 7611 & $\begin{array}{c}3.8 \\
(289)\end{array}$ & $\begin{array}{c}1.8 \\
(136)\end{array}$ & $\begin{array}{c}1.8 \\
(140)\end{array}$ & $\begin{array}{c}2.1 \\
(160)\end{array}$ & $\begin{array}{c}.8 \\
(62)\end{array}$ & $\begin{array}{c}.9 \\
(70)\end{array}$ \\
\hline \multicolumn{8}{|l|}{ Control Groups } \\
\hline $\begin{array}{l}\text { Poor single women without } \\
\text { children (Controll) }\end{array}$ & 3297 & $\begin{array}{r}7.6 \\
(252)\end{array}$ & $\begin{array}{l}3.6 \\
(120)\end{array}$ & & & & \\
\hline Poor single men (Control2) & 5458 & $\begin{array}{r}6.9 \\
(381)\end{array}$ & $\begin{array}{l}3.6 \\
(199)\end{array}$ & & & & \\
\hline Poor married men (Control3) & 1072 & $\begin{array}{l}6.2 \\
(66)\end{array}$ & $\begin{array}{l}3.2 \\
(34)\end{array}$ & & & & \\
\hline $\begin{array}{l}\text { Poor Married Women } \\
\text { (Control4) }\end{array}$ & 1344 & $\begin{array}{l}4 . \overline{8} \\
(64)\end{array}$ & $\begin{array}{l}2.2 \\
(30)\end{array}$ & & & & \\
\hline Total Controls & 11171 & $\begin{array}{l}6.8 \\
(763)\end{array}$ & $\begin{array}{l}3.4 \\
(383)\end{array}$ & & & & \\
\hline Total Observations & 18782 & $\begin{array}{c}5.6 \\
(1052)\end{array}$ & $\begin{array}{l}2.7 \\
(519)\end{array}$ & & & & \\
\hline
\end{tabular}




\begin{tabular}{|c|c|c|c|c|c|}
\hline & & Table 2 & & & \\
\hline & Desc & tive Stati & & & \\
\hline Variable & Treatement & Control l & Control 2 & $\overline{\text { Control } 3}$ & Control 4 \\
\hline Sex & Female & Female & Male & Male & Female \\
\hline Poverty Status & Poor & Poor & Poor & Poor & Poor \\
\hline Have Children? & Yes & No & .072 & .817 & .855 \\
\hline (fraction if yes) & & & $(.259)$ & $(.387)$ & $(.351)$ \\
\hline Married & No & No & No & Yes & Yes \\
\hline 8Received AFDC in $t$ or $t-1$ & 75 & 0 & 0 & 0 & 0 \\
\hline Age $(1979)$ & 17.8 & 17.4 & 17.39 & 18.15 & 18.11 \\
\hline & $(2.19)$ & $(2.14)$ & $(2.12)$ & 12.291 & $(2.21)$ \\
\hline Highest Grade Attained & 10.98 & 12.38 & 11.35 & 10.61 & 10.43 \\
\hline & $(1.93)$ & $(2.21)$ & $(2.32)$ & 12.591 & $(2.56)$ \\
\hline Black & .528 & .347 & .455 & .211 & .217 \\
\hline & $(.499)$ & $(.476)$ & $(.498)$ & 1.4081 & $(.412)$ \\
\hline Maximum Benefit (avg) & 364 & 363 & 362 & 339 & 341 \\
\hline & (85) & 1791 & (77) & $170)$ & $(80)$ \\
\hline Moved across county within & .115 & .210 & .218 & .186 & .149 \\
\hline state & $(.320)$ & $(.407)$ & $(.413)$ & $(.389)$ & $(.357)$ \\
\hline Moved to different state & .034 & .076 & .069 & .062 & .048 \\
\hline & $(.181)$ & $(.265)$ & $(.254)$ & $(1.240)$ & $(.213)$ \\
\hline Live in $B(100)$ state? & .400 & .377 & .405 & .446 & .358 \\
\hline & $(.490)$ & $(.484)$ & $(.491)$ & 1.4971 & $(.479)$ \\
\hline Live in $B(200)$ state? & .280 & .322 & .306 & .371 &. .443 \\
\hline & $(.449)$ & $(.467)$ & $(.461)$ & 1.4831 & $(.497)$ \\
\hline Distance to $B(100)$ state? & 187 & 179 & 191 & 207 & 184 \\
\hline & $(346)$ & (339) & $(343)$ & $(340)$ & $(350)$ \\
\hline Distance to $B(200)$ state? & 242 & 271 & 272 & 368 & 437 \\
\hline & $(436)$ & $(448)$ & $(470)$ & $(568)$ & $(587)$ \\
\hline Crimes per 100,000 pop & 5789 & 5880 & 5817 & 5673 & 5856 \\
\hline & $(1204)$ & $(1363)$ & $(1299)$ & $(1497)$ & $(1490)$ \\
\hline State per capita income & 13952 & 12532 & 13079 & 13468 & 12837 \\
\hline & $(3343)$ & $(2932)$ & $(3114)$ & $(2898)$ & $(2809)$ \\
\hline Number of Person Years & 5690 & 3297 & 5458 & 1072 & 1344 \\
\hline
\end{tabular}


Table 3

Probit: Dependent Variable is probability of moving to a different state

\begin{tabular}{|c|c|c|c|c|c|}
\hline & Control 1 & Control 2 & Control 3 & Control 4 & $\begin{array}{l}\text { Pooled } \\
\text { Controls }\end{array}$ \\
\hline I. Continuous Treatment Effect": & $\begin{array}{l}.252 \\
(.548) \\
\end{array}$ & $\begin{array}{l}.056 \\
(.509) \\
\end{array}$ & $\begin{array}{l}-.545 \\
(.836) \\
\end{array}$ & $\begin{array}{c}-.512 \\
(.757)\end{array}$ & $\begin{array}{l}-.094 \\
(.473) \\
\end{array}$ \\
\hline \multicolumn{6}{|l|}{ II. Discrete Treatment Effect } \\
\hline \multicolumn{6}{|l|}{ A. Basic Model } \\
\hline Potential increase in Benefits $\$ 100-\$ 200^{\prime \prime}$ & $\begin{array}{l}-1.34 \\
(1.00)\end{array}$ & $\begin{array}{l}-.941 \\
(.917)\end{array}$ & $\begin{array}{l}-.673 \\
(1.63)\end{array}$ & $\begin{array}{l}.369 \\
(1.50)\end{array}$ & $\begin{array}{c}-.943 \\
(.851)\end{array}$ \\
\hline Potential increase in Benefits $\$ 200+^{\prime \prime}$ & $\begin{array}{l}-.856 \\
(1.07) \\
\end{array}$ & $\begin{array}{l}-.295 \\
(1.01)\end{array}$ & $\begin{array}{l}.027 \\
(1.74)\end{array}$ & $\begin{array}{l}2.33 \\
(1.70)\end{array}$ & $\begin{array}{l}-.057 \\
(.954) \\
\end{array}$ \\
\hline \multicolumn{6}{|l|}{ B. Distance Model } \\
\hline Potential increase in Benefits $\$ 100-\$ 200^{m}$ & $\begin{array}{l}-1.18 \\
(1.24) \\
\end{array}$ & $\begin{array}{l}-.011 \\
(1.16)\end{array}$ & $\begin{array}{l}.929 \\
(2.00)\end{array}$ & $\begin{array}{l}-.483 \\
(1.82)\end{array}$ & $\begin{array}{c}-.296 \\
(1.07)\end{array}$ \\
\hline Potential increase in Benefits $\$ 200+$ & $\begin{array}{l}-3.11 \\
(1.68)\end{array}$ & $\begin{array}{l}-1.18 \\
(1.72)\end{array}$ & $\begin{array}{l}-.520 \\
(2.61)\end{array}$ & $\begin{array}{l}-1.73 \\
(2.27)\end{array}$ & $\begin{array}{l}-2.11 \\
(1.50)\end{array}$ \\
\hline $\begin{array}{l}\text { Potential increase in Benefits } \$ 100- \\
\$ 200^{*} \text { Distance }\end{array}$ & $\begin{array}{l}-.029 \\
(.152)\end{array}$ & $\begin{array}{l}-.187 \\
(.133)\end{array}$ & $\begin{array}{l}-.303 \\
(.191)\end{array}$ & $\begin{array}{l}.173 \\
(.222)\end{array}$ & $\begin{array}{l}-.130 \\
(.126)\end{array}$ \\
\hline Potential increase in Benefits $\$ 200+^{\star}$ Distance & $\begin{array}{l}.328 \\
(.196)\end{array}$ & $\begin{array}{l}.110 \\
(.169)\end{array}$ & $\begin{array}{l}.078 \\
(.205)\end{array}$ & $\begin{array}{l}.437 \\
(.225)\end{array}$ & $\begin{array}{l}.266 \\
(.160)\end{array}$ \\
\hline \multicolumn{6}{|c|}{$\begin{array}{l}\text { Derivative multiplied by } 10,000 \\
\text { Derivative multiplied by } 100 \\
\text { standard errors in parenthesis. } \\
\text { Note: Treatment group = poor single women on AFDC in past two years or not. Control group } 1=\text { poor single } \\
\text { women without children. Control group } 2=\text { poor single men. Control group } 3=\text { poor married men. Control group } \\
4=\text { poor married women. }\end{array}$} \\
\hline
\end{tabular}


Table 4

Probit: Dependent Variable is probability of moving to a different state (includes additional control variables)

\begin{tabular}{|c|c|c|c|c|c|}
\hline & Control 1 & Control 2 & Control 3 & Control 4 & \begin{tabular}{|l|} 
Pooled \\
Controls
\end{tabular} \\
\hline I. Continuous Treatment Effect": & $\begin{array}{l}.069 \\
(.54) \\
\end{array}$ & $\begin{array}{c}-.065 \\
(.501)\end{array}$ & $\begin{array}{l}-.666 \\
(.830) \\
\end{array}$ & $\begin{array}{c}-.554 \\
(.747)\end{array}$ & $\begin{array}{c}-.171 \\
(.463) \\
\end{array}$ \\
\hline \multicolumn{6}{|l|}{ II. Discrete Treatment Effect } \\
\hline \multicolumn{6}{|l|}{ A. Basic Model } \\
\hline Potential increase in Benefits $\$ 100-\$ 200^{\prime F}$ & $\begin{array}{c}-1.23 \\
(1.00)\end{array}$ & $\begin{array}{c}-.657 \\
(.918)\end{array}$ & $\begin{array}{l}-.952 \\
(1.62)\end{array}$ & $\begin{array}{l}557 \\
(1.49)\end{array}$ & $\begin{array}{c}-.736 \\
(.847)\end{array}$ \\
\hline Potential increase in Benefits $\$ 200+^{\circ}$ & $\begin{array}{c}-.596 \\
(1.07)\end{array}$ & $\begin{array}{c}-.097 \\
(1.00)\end{array}$ & $\begin{array}{c}-.315 \\
(1.72) \\
\end{array}$ & $\begin{array}{l}2.31 \\
(1.68) \\
\end{array}$ & $\begin{array}{l}.035 \\
(.942) \\
\end{array}$ \\
\hline \multicolumn{6}{|l|}{ B. Distance Model } \\
\hline Potential increase in Benefits $\$ 100-\$ 200^{\prime \prime}$ & $\begin{array}{c}-1.23 \\
(1.22)\end{array}$ & $\begin{array}{l}.347 \\
(1.16)\end{array}$ & $\begin{array}{l}.714 \\
(1.98)\end{array}$ & $\begin{array}{c}-.204 \\
(1.82)\end{array}$ & $\begin{array}{l}-.127 \\
(1.06)\end{array}$ \\
\hline Potential increase in Benefits $\$ 200+^{\prime \prime}$ & $\begin{array}{l}-2.43 \\
(1.70)\end{array}$ & $\begin{array}{l}-.838 \\
(1.69)\end{array}$ & $\begin{array}{l}-.698 \\
(2.54)\end{array}$ & $\begin{array}{l}-1.61 \\
(2.25)\end{array}$ & $\begin{array}{l}-1.60 \\
(1.51)\end{array}$ \\
\hline Potential increase in Benefits $\$ 100-\$ 200^{\star}$ Distance & $\begin{array}{l}.014 \\
(.147)\end{array}$ & $\begin{array}{l}-.168 \\
(.127)\end{array}$ & $\begin{array}{l}-.297 \\
(.188)\end{array}$ & $\begin{array}{l}.154 \\
(.219)\end{array}$ & $\begin{array}{l}-.098 \\
(.121)\end{array}$ \\
\hline Potential increase in Benefits $\$ 200+^{\star}$ Distance & $\begin{array}{l}.247 \\
(.190)\end{array}$ & $\begin{array}{l}.091 \\
(.162)\end{array}$ & $\begin{array}{l}.067 \\
(.198)\end{array}$ & $\begin{array}{l}.421 \\
(.221)\end{array}$ & $\begin{array}{l}.208 \\
(.154)\end{array}$ \\
\hline \multicolumn{6}{|c|}{ 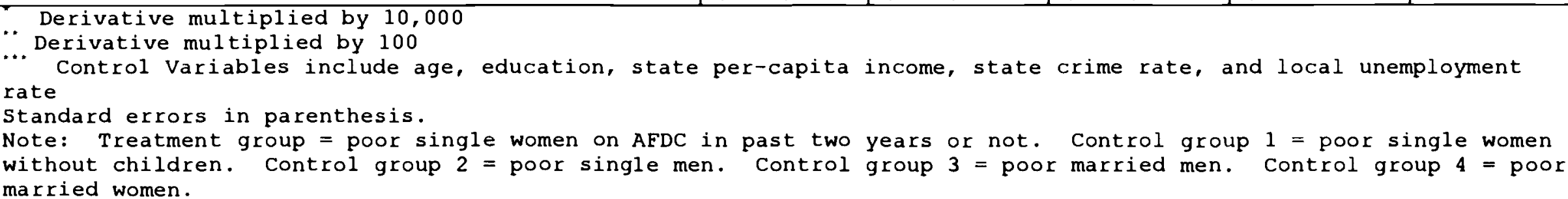 } \\
\hline
\end{tabular}


Table 5

Probit: Dependent Variable is probability of moving to a higher benefit state

\begin{tabular}{|c|c|c|c|c|c|}
\hline & Control 1 & Control 2 & Control 3 & Control 4 & $\begin{array}{l}\text { Pooled } \\
\text { Controls }\end{array}$ \\
\hline I. Continuous Treatment Effect & $\begin{array}{l}.493 \\
(.390) \\
\end{array}$ & $\begin{array}{l}.143 \\
(.371) \\
\end{array}$ & $\begin{array}{l}-.325 \\
(.573)\end{array}$ & $\begin{array}{l}.082 \\
(.587)\end{array}$ & $\begin{array}{l}.156 \\
(.352)\end{array}$ \\
\hline \multicolumn{6}{|l|}{ II. Discrete Treatment Effect } \\
\hline \multicolumn{6}{|l|}{ A. Basic Model } \\
\hline Potential increase in Benefits $\$ 100-\$ 200^{*}$ & $\begin{array}{l}-1.29 \\
(.782)\end{array}$ & $\begin{array}{l}-.821 \\
(.722) \\
\end{array}$ & $\begin{array}{l}-.611 \\
(1.44)\end{array}$ & $\begin{array}{l}-.942 \\
(1.33)\end{array}$ & $\begin{array}{l}-1.01 \\
(.660)\end{array}$ \\
\hline Potential increase in Benefits $\$ 200+$ & \begin{tabular}{|l|}
-.956 \\
$(.767)$ \\
\end{tabular} & \begin{tabular}{|l|}
-.265 \\
$(.766)$ \\
\end{tabular} & $\begin{array}{l}-.461 \\
(1.41)\end{array}$ & $\begin{array}{l}.014 \\
(1.43)\end{array}$ & $\begin{array}{l}-.457 \\
(.708) \\
\end{array}$ \\
\hline \multicolumn{6}{|l|}{ B. Distance Model } \\
\hline Potential increase in Benefits $\$ 100-\$ 200^{*}$ & \begin{tabular}{|c|}
-.714 \\
$(.926)$
\end{tabular} & \begin{tabular}{|c|}
-.517 \\
$(.842)$
\end{tabular} & $\begin{array}{l}.695 \\
(1.73)\end{array}$ & $\begin{array}{l}-.609 \\
(1.48)\end{array}$ & $\begin{array}{l}-.487 \\
(.804)\end{array}$ \\
\hline Potential increase in Benefits $\$ 200+$ & \begin{tabular}{|c|}
-1.74 \\
$(.886)$ \\
\end{tabular} & \begin{tabular}{|l|}
-.621 \\
$(1.01)$ \\
\end{tabular} & $\begin{array}{l}-.076 \\
(1.78)\end{array}$ & $\begin{array}{l}-1.42 \\
(1.37) \\
\end{array}$ & $\begin{array}{l}-1.15 \\
(.858)\end{array}$ \\
\hline Potential increase in Benefits $\$ 100-\$ 200^{\star}$ Distance & $\begin{array}{l}-.140 \\
(.088)\end{array}$ & $\begin{array}{l}-.075 \\
(.087)\end{array}$ & $\begin{array}{l}-.239 \\
(.106)\end{array}$ & $\begin{array}{l}-.072 \\
(.117)\end{array}$ & $\begin{array}{l}-.131 \\
(.084)\end{array}$ \\
\hline Potential increase in Benefits $\$ 200+^{\star}$ Distance & $\begin{array}{l}.150 \\
(.097) \\
\end{array}$ & $\begin{array}{l}.046 \\
(.087) \\
\end{array}$ & $\begin{array}{l}-.030 \\
(.098)\end{array}$ & $\begin{array}{l}.202 \\
(.115)\end{array}$ & $\begin{array}{l}.105 \\
(.082)\end{array}$ \\
\hline \multicolumn{6}{|c|}{$\begin{array}{l}\text { Derivative multiplied by } 10,000 \\
\text { Derivative multiplied by } 100 \\
\text { Standard errors in parenthesis. } \\
\text { Note: Treatment group }=\text { poor single women on AFDC in past two years or not. Control group } 1=\text { poor single women } \\
\text { without children. Control group } 2=\text { poor single men. Control group } 3=\text { poor married men. Control group } 4=\text { poor } \\
\text { married women. }\end{array}$} \\
\hline
\end{tabular}


Table 6

Probit: Dependent Variable is probability of moving to a higher benefit state (includes additional control variables)

\begin{tabular}{|c|c|c|c|c|c|}
\hline & Control 1 & Control 2 & Control 3 & Control 4 & $\begin{array}{l}\text { Pooled } \\
\text { Controls }\end{array}$ \\
\hline I. Continuous Treatment Effect & $\begin{array}{l}.411 \\
(.370)\end{array}$ & $\begin{array}{l}.159 \\
(.364)\end{array}$ & $\begin{array}{l}-.447 \\
(.544)\end{array}$ & $\begin{array}{l}.106 \\
(.565)\end{array}$ & $\begin{array}{l}.172 \\
(.342)\end{array}$ \\
\hline \multicolumn{6}{|l|}{ II. Discrete Treatment Effect } \\
\hline \multicolumn{6}{|l|}{ A. Basic Model } \\
\hline Potential increase in Benefits $\$ 100-\$ 200^{\circ}$ & $\begin{array}{c}-1.21 \\
(.733)\end{array}$ & \begin{tabular}{|c|}
-.804 \\
$(.708)$
\end{tabular} & \begin{tabular}{|l|}
-.646 \\
$(1.35)$
\end{tabular} & $\begin{array}{l}-.739 \\
(1.25)\end{array}$ & $\begin{array}{l}-1.01 \\
(.638)\end{array}$ \\
\hline Potential increase in Benefits $\$ 200+^{\circ /}$ & $\begin{array}{l}-.837 \\
(.727)\end{array}$ & $\begin{array}{l}-.182 \\
(.758)\end{array}$ & $\begin{array}{c}-.434 \\
(1.34)\end{array}$ & $\begin{array}{l}.053 \\
(1.34)\end{array}$ & $\begin{array}{l}-.425 \\
(.689)\end{array}$ \\
\hline \multicolumn{6}{|l|}{ B. Distance Model } \\
\hline Potential increase in Benefits $\$ 100-\$ 200^{*}$ & \begin{tabular}{|c|}
-.723 \\
$(.864)$
\end{tabular} & $\begin{array}{l}-.500 \\
(.823)\end{array}$ & $\begin{array}{l}.613 \\
(1.62)\end{array}$ & $\begin{array}{l}-.241 \\
(1.43)\end{array}$ & $\begin{array}{l}-.517 \\
(.777)\end{array}$ \\
\hline Potential increase in Benefits $\$ 200+^{*}$ & $\begin{array}{c}-1.57 \\
(.840)\end{array}$ & \begin{tabular}{|c|}
-.538 \\
$(1: 00)$
\end{tabular} & $\begin{array}{l}-.157 \\
(1.66)\end{array}$ & $\begin{array}{l}-1.37 \\
(1.26)\end{array}$ & $\begin{array}{c}-1.04 \\
(.846)\end{array}$ \\
\hline Potential increase in Benefits $\$ 100-\$ 200^{\star}$ Distance & $\begin{array}{l}-.115 \\
(.082)\end{array}$ & $\begin{array}{l}-.066 \\
(.084)\end{array}$ & $\begin{array}{l}-.220 \\
(.101)\end{array}$ & $\begin{array}{l}-.099 \\
(.111)\end{array}$ & $\begin{array}{l}-.118 \\
(.081)\end{array}$ \\
\hline Potential increase in Benefits $\$ 200+^{\star}$ Distance & $\begin{array}{l}.138 \\
(.092)\end{array}$ & $\begin{array}{l}.048 \\
(.085)\end{array}$ & $\begin{array}{l}-.018 \\
(.092)\end{array}$ & $\begin{array}{l}.201 \\
(.110)\end{array}$ & $\begin{array}{l}.092 \\
(.079)\end{array}$ \\
\hline \multicolumn{6}{|c|}{$\begin{array}{l}\text { Derivative multiplied by } 10,000 \\
\text {... Derivative multiplied by } 100 \\
\text { Control Variables include age, education, state per-capita income, state crime rate, and local unemployment } \\
\text { rate } \\
\text { standard errors in parenthesis. } \\
\text { Note: Treatment group }=\text { poor single women on AFDC in past two years or not. Control group } 1=\text { poor single women } \\
\text { ithout children. Control group } 2=\text { poor single men. Control group } 3=\text { poor married men. Control group } 4=\text { poor } \\
\text { married women. }\end{array}$} \\
\hline
\end{tabular}


To order any of these papers, see instructions at the end of the list. To subscribe to all NBER Working Papers or the papers in a single area, see instructions inside the back cover. A complete list of NBER Working Papers and Reprints can be accessed on the Internet by using our gopher at nber.harvard.edu.

Number

5211

5212

5213

5214

5215

5216
Author(s)

Alwyn Young

Benjamin M. Friedman

Robert B. Barsky

Miles S. Kimball

F. Thomas Juster

Matthew D. Shapiro

Alberto Alesina

Roberto Perotti

John F. Helliwell

William H. Dow

Jessica Holmes

Tomas Philipson

Xavier Sala-i-Martin

Jeremy C. Stein

Joel Slemrod

Andrew K. Rose

Paul Krugman

Anthony J. Venables

Ann Harrison

Geoffrey Carliner

Robin L. Lumsdaine

David Neumark

William Wascher

Ann Harrison

Ana Revenga
Title

Date

Growth Without Scale Effects

$8 / 95$

Does Monetary Policy Affect Real Economic

$8 / 95$

Activity?: Why Do We Still Ask This Question?

Preference Parameters and Behavioral

$8 / 95$

Heterogeneity: An Experimental Approach in the Health and Retirement Survey

Fiscal Expansions and Fiscal Adjustments in OECD Countries

Do National Borders Matter for Quebec's Trade?

$8 / 95$

Disease Complementarities and the Evaluation of Public Health Interventions

$8 / 95$

An Adverse Selection Model of Bank Asset and Liability Management with Implications for the Transmission of Monetary Policy

High-Income Families and the Tax Changes of the 1980s: The Anatomy of Behavioral Response

$8 / 95$

After the Deluge: Do Fixed Exchange Rates

$8 / 95$ allow Inter-Temporal Volatility Tradeoffs?

The Seamless World: A Spatial Model of International Specialization

$8 / 95$

Openness and Growth: A Time-Series, Cross-

Country Analysis for Developing Countries

$8 / 95$

The Language Ability of U.S. Immigrants: Assimilation and Cohort Effects

$8 / 95$

Factors Affecting Labor Supply Decisions and Retirement Income

$8 / 95$

The Effect of New Jersey's Minimum Wage

$8 / 95$ Increase on Fast-Food Employment: A Re-Evaluation Using Payroll Records

The Effects of Trade Policy Reform: What 